\title{
COMMENT
}

\section{OBVIATING THE NECESSITY FOR CONSIDERATION IN AMENDATORY AGREEMENTS}

EnI E. Fink*

W HEN a business man is advised by his lawyer that his solemn promise, even though reduced to writing, cannot be enforced against him for lack of the legal formula known as consideration, his opinion of the legerdemain of his lawyer rises but his respect for the law suffers. And when a business man is told that he has no legal redress for the breach of another's written obligation to him by virtue of the lack of the same technical requirement of consideration, his contempt for both lawyers and the law swells to unseemly proportions.

It is not the purpose of this comment, however, to add another voice to that chorus of criticism which has advocated the abolition of legal con-

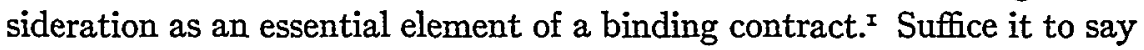
that other countries have developed their contract law without the requirement of consideration, and it appears that the requirement entered our Anglo-American system through the back door of ancient rules of pleading. ${ }^{2}$ The scope of this comment will be limited to the examination of one of the practical problems arising from the requirement of consideration and to the suggestion of a workable and"simple solution of it.

Contractual relations are usually initiated in the business world as the result of bargains or bilateral deals, and hence no difficulty is normally experienced in finding the element of consideration in the mutual engage-

* Member of the Illinois Bar.

${ }^{2}$ Mason, The Utility of Consideration-A Comparative View, 4I Col. L. Rev. 825, 844-45 (194I); Wright, Ought the Doctrine of Consideration to Be Abolished from the Common Law?, 49 Harv. L. Rev. I225, I252-53 (1936); Lorenzen, Causa and Consideration in the Law of Contracts, 28 Yale L. J. 621, 646 (rgI9); Ashley, The Doctrine of Consideration, 26 Harv. L. Rev. 429 (I913); Jaffray v. Davis, I24 N.Y. 164, I67, 26 N.E. 351, 352 (I89I); Smith v. Ballou, I R.I. 496, 498 (185x); Clayton v. Clark, 74 Miss. 499, 506-ro, 2I So. 565, 568-69 (I897); see Shelton v. Jackson, 49 S.W. 4I 5, 4I9 (Tex. Civ. App. 1899).

2 I Williston, Contracts $\$ 99$ (rev. ed. I936); Jenks, Law and Politics in the Middle Ages 286 (IgIg); Jenks, The Doctrine of Consideration I6I, 2I9 (I892); I2 Am. Jur., Contracts $\S 72$ (1938); Ames, The History of Assumpsit, 2 Harv. L. Rev. I, 2 (1888); Ames, Parol Contracts Prior to Assumpsit, 8 Harv. L. Rev. 252 (I894); Lorenzen, op. cit. supra note r, at 62r. 
ments of the parties. The problem to be considered pertains to one-sided, gratuitous amendments of existing contractual relations. It is encountered in connection with the gratuitous revision of any and every variety of contractual arrangement, whether it be an employment contract, ${ }^{3}$ construction contract, ${ }^{4}$ mortgage, ${ }^{5}$ trust agreement, ${ }^{6}$ negotiable instrument, ${ }^{7}$ or contract to buy or sell any kind of property. ${ }^{8}$. A typical situation is that in which a tenant requests a rental reduction and his landlord, recognizing that the reduced rental will be no less than the market value of the premises and that his tenant is judgment proof or will be rendered insolvent by paying the lease rental, agrees to reduce the rent for a specified period of time. Then, after the reduced rent is paid and accepted for a number of months, the landlord changes his mind and claims the difference between the lease and the reduced rental for the expired portion of the period and cancels the agreement for the balance of the period. Under those circumstances the tenant will learn that the law permits his landlord to be an "Indian giver."

Such revocable generosity results in grave injustice to the tenant for, if he knew that he must eventually go through bankruptcy or some other

3 Schneller v. Hayes, 176 Wash. Ir5, 28 P. (2d) 273 (I934) (employee's promise in writing not to compete, made after oral employment contract); Benedict v. Pincus, $\mathbf{r}_{34}$ App. Div. 555, Irg N.Y. Supp. 266 (Ig09); Swee v. Neumann, 67 Misc. 605, I23 N.Y. Supp. 776 (Munic. Ct. IgIO).

4 Graef v. Bowles, IIg Ore. 498, 248 Pac. Iogo (I926); Gotterer v. South River Spinning Co., 199 N.Y. Supp. 542 (S.Ct. I923).

5 Chilson v. Bank of Fairmount, 9 N.D. $96,8 \mathrm{I}$ N.W. 33 (I899); Wendover v. Baker, I2x Mo. 273, 25 S.W. 918 (1894).

6 Wildey v. Robinson, 85 Hun 362, 32 N.Y. Supp. Ior8 (1895).

7 Parmelee v. Thompson, 45 N.Y. 58 (187r); Pemberton \& Pemberton v. Hoosier \& Overshiner, I Kan. Io8 (r862).

${ }^{8}$ McQuaid v. Baughman, r67 Ill. App. 430, 437 (r9r2) (stock sale); Berlant Development Co. v. McManus, 97 N.J. Eq. 438 ,.128 Atl. 785 (r925) (conveyance of real estate); Jeffries v. Pankow, II2 Ore. 439, 223 Pac. 745 (I924) (conditional sale); Western Lithograph Co. v. Vanomar Producers, I85-Cal. 366, I97 Pac. I03 (1921) (contract to deliver labels for five years).

9 Gordon v. Green, 5I Cal. App. 765, I97 Pac. 955 (I92I) (revocation of executed as well as executory portion of rental reduction agreement); Druid Hills, Inc. v. Doughman, I7I Ga. 52I, 156 S.E. 229 (1930) (promise of judgment creditor to allow debtor one year to refinance property in consideration of substantial payment on debt); Fienberg v. Adelman, 260 Mass. ${ }^{4} 43,{ }_{5} 6$ N.E. 896 ( 1927 ) (gratuitous option to renew lease); Boerger v. Vandegrift, I88 S.W. 948 (Tex. Civ. App. I9I6) (promise to reduce rent if lessee would vacate premises promptly at end of lease); Loth v. Harris, 76 Misc. 505, ${ }_{35}$ N.Y. Supp. 553 (S. Ct. r9r2) (promise to allow lessee credit on rent if he completed alterations he was bound to make). Some courts have, however, allowed the lessor to repudiate the executory but not the executed part of a rental reduction agreement. Levy v. Greenberg, 26I Ill. App. 54I (I93I); Snow v. Griesheimer, 220 Ill. I06, 77 N.E. I10 (igo6); I Williston, Contracts § I20, at 4I7 (rev. ed. I936). 
form of reorganization to escape his onerous lease, he would much prefer to do so at the time when his business was in such serious straits that his landlord agreed that he was entitled to relief from his rental obligation rather than at the time when business conditions were so improved that his landlord believed it would be expedient to repudiate the rent reduction. The landlord, on the other hand, is deserving of little sympathy, particularly in respect to the expired portion of the rental reduction period, because he received during those months all that the premises were worth and all that he thought the tenant could afford to pay. It may be argued that when the promisor under a gratuitous amendment is permitted to repudiate the amendment for want of consideration, the promisee under the gratuitous amendment does not merit our commiseration for he is then required to do no more than comply with his original agreement. The promise in the original agreement, however, should not be any more sacred than the promise in the amendment, and it would seem that the most recent expression of the compact of the parties should be enforced in preference to a mutually abandoned statement of their intentions.

Preventing promisors under gratuitous amendments of contractual arrangements from having the right to revoke such amendments has been the difficult task of lawyers representing persons in the position of the promisee under such amendments, such as the tenant in the illustration given above. In some states the inscription of the word "seal" after the names of the parties is still supposed to have its ancient efficacy in binding the parties despite the lack of consideration..$^{\text {I0 }}$ Even in such jurisdictions, however, lawyers are reluctant to rely on the seal as a substitute for consideration for fear that theirs might be the very case in which, if the point were again presented to a modern court, the court would decide to reverse the precedents and abandon the hoary sanctity of the seal. ${ }^{\mathrm{Ix}}$ In addition,

${ }^{10}$ Curry v. Cotton, 356 Ill. 538, I9r N.E. 307 (1934);Florida Asphalt Pavement Mfg. Co. v. Federal Reserve Bank, 76 F. (2d) 326 (C.C.A. $5^{\text {th }}$ I935) (applying Florida common law); Newburyport Society for Relief of Aged Women v. Noyes, 287 Mass. 530, I92 N.E. 54 (I934); I Williston, Contracts $\S$ Iog (rev. ed. I936); I2 Am. Jur., Contracts $\S 74$ (I938). It should be noted, however, that in these cases and in many of the cases holding that a sealed instrument need not have consideration, the courts found other consideration besides the seal to make the agreement legally enforceable.

II For discussions of the confusion and uncertainty in many states, including Ilinois, concerning the effectiveness of the seal as a substitute for consideration, see The Present Status of the Sealed Obligation, 34 IIl. L. Rev. 457 (I939); Contracts without Consideration; the Seal and the Uniform Written Obligations Act, 3 Univ. Chi. L. Rev. 3 12 (1936). In Bender v. Been, 78 Iowa 283,43 N.W. 216 ( 1889 ), the court said, at pages 285 and 217 : "It . . . cannot be claimed that a sealed instrument imports a valid consideration when it shows, by its own conditions and recitations, that it is in fact not founded upon a consideration." 
many states have declared by statute either that the presumption of consideration in sealed instruments may be rebutted or that sealed instruments shall not enjoy any privileges denied their unsealed brethren..$^{12}$ Another device sometimes relied on is the recital that the tenant has made a nominal monetary payment, the receipt of which is acknowledged by the landlord. Aside from the fact that the landlord is usually able to prove, and is not barred by the parol evidence rule from proving, that no such payment was made, ${ }^{\mathrm{x}}$ the small payment is never the price or bargain for which the rent reduction was given and consequently it is not valid consideration. ${ }^{14}$ Another subterfuge to fabricate consideration for a rent reduction consists of a covenant by the tenant, in consideration of obtaining the rent reduction, to perform some trivial duty which he was not theretofore obligated to perform under the terms of the lease, such as sweeping snow from the sidewalk. Such devices are, however, of dubious utility in supplying the required consideration for the same reason that the tenant's payment of one dollar fails to accomplish its purpose, namely, the landlord has not, as a matter of fact, bargained to reduce the rent in consideration of receiving the sum of one dollar or the covenant of the tenant to keep the sidewalk clear of snow.

It is true that the courts have, on occasion, dispensed with the requirement of consideration when compelled to do so in order to avoid particularly inequitable results. ${ }^{15}$ Such decisions, however, lacking a frank dis-

I2 New York recently adopted an act which denies legal effect to the presence or absence of a seal. N.Y.L. (I94r) c. $329, \S 2$. This statute was enacted despite the New York Court of Appeals' eulogy of consideration as a protective device. Cochran v. Taylor, 273 N.Y. I72, I 79, 7 N.E. (2d) 89, 9r (I937). Other statutes are collected in I Williston, Contracts § 218 (rev. ed. I936); The Present Status of the Sealed Obligation, 34 III. L. Rev. 457 (I939); Contracts without Consideration; the Seal and the Uniform Written Obligations Act, 3 Univ. Chi. L. Rev. 3I2 (I936).

${ }^{23}$ Brinkman v. Empire Gas \& Fuel Co., I20 Kan. 602, 245 Pac. I07 (I926); Kay v. Spencer' 29 Wyo. 382, 213 Pac. 57 I (I923); Rest., Contracts $\$ \S 75,82$ (I932); I2 Am. Jur., Contracts $\S$ I20 (I938); I Williston, Contracts $\S$ II5B (rev. ed. I936). Contra: cases cited I Williston, Contracts $\S \mathrm{II}$ B B, at $400-40 \mathrm{Im}$. Io-I2 (rev. ed. I936); Gillespie v. Fulton Oil \& Gas Co., 236 IIl. I88, 200, 86 N.E. 219, 224 (Ig08). It should be noted that the court in the latter case said, "It is inconceivable that the money consideration mentioned in this lease [one dollar] was the real consideration upon which it rested. Undoubtedly the real consideration was the exploitation of the mineral resources. ...."

${ }^{14}$ "Consideration must actually be bargained for as the exchange for the promise. A statement that a consideration has been bargained for does not conclusively prove the fact." Rest., Contracts § 75, comment B (1932); Hammond Oil Co. v. Standard Oil Co., 259 N.Y. 312, 18I N.E. 583 (I932); I2 Am. Jur., Contracts $\S 75$ (I938); I Williston, Contracts $\S$ roo (rev. ed. I936).

${ }^{15}$ Devious means have been found to avoid the consideration requirement and to support gratuitous amendments to original contracts. In Levy v. Greenberg, 26I Ill. App. 54I (I93I), 
avowal of the requirement of consideration and resting on tenuous reasoning applied to the peculiar circumstances of each case, cannot be relied upon as precedents with confidence.

Section 90 of the Restatement of the Law of Contracts endeavors to lead the courts a few steps along the path of enforcing certain promises lacking consideration. ${ }^{16}$ However, the court under this section must find, as conditions precedent to enforcement of the promise, that the promisee has suffered a substantial detriment, that the promisor must have reasonably foreseen that his promise would result in the promisee's suffering such detriment, and that injustice will result unless the promise is enforced. These requirements are so amorphous and yet stringent that the utility of the section is bound to be limited.

With the courts so reluctant to repudiate the requirement of consideration and so devious in their methods when induced to do so, efforts have been made to enlist the legislatures to revise the common law rule of con-

the difference between the lease and reduced rental was treated as an irrevocable gift, and in Steward \& Howell v. Keteltas, 36 N.Y. 388,2 Trans. App. 288 (I867), the owner was deemed to have released the contractor for his breach of contract and then the contractor's subsequent promise to do the work was treated as a consideration for the owner's promise to pay the additional sum. The latter view is lauded by Ames, Two Theories of Consideration, 12 Harv. L. Rev. 515, 528 (1899). The court in Coyner v. Lynde, Io Ind. 282 (1858), found consideration for the promise to pay an additional sum by concluding that the original agreement was abandoned when the other party refused to proceed because of the inadequate price. In Bishop v. Busse, $69 \mathrm{Mll} .403$ ( 1873 ), the court held that the owner was bound to pay the additional sum he agreed to pay the contractor in order to induce the contractor to fulfill the original contract by realistically concluding, at page 407 , that ". . . appellant [the owner] could have recovered the damages occasioned by the breach. But this he may have considered of less advantage to him than the completion of the building, and if so, that of itself would have been a sufficient consideration to support the new agreement." Parrot v. Mexican Central R. Co., 207 Mass. I84, 93 N.E. 590 (I9II), states that a promise to pay additional money to secure performance of the other party's promise instead of relying on the right to collect damages is binding but warns, at pages $194-95$ and 594 , that "this limitation is not intended to affect the rule that a contract cannot be binding without a consideration; but it rests upon the doctrine that, under these circumstances, there is a new consideration for the promise." In Schwartzreich v. Bauman-Basch, Inc., 23I N.Y. I96, I3I N.E. 887 (I92I), consideration for the promise of an employer to pay a higher salary than provided for in an existing employment agreement was found in the cancellation of the existing agreement simultaneously with the increase of the salary, but this result was criticized by Williston, Law of Contracts since the Restatement, 23 A.B.A.J., I72, 174 (1937). In the case of In re Carter's Estate, 70 Minn. 77, 72 N.W. 826 (1897), consideration was found in the payment of a smaller amount to satisfy a liquidated debt on the ground that the debtor was thought to be insolvent.

${ }^{26}$ "A promise which the promisor should reasonably expect to induce action or forbearance of a definite and substantial character on the part of the promisee and which does induce such action or forbearance is binding if injustice can be avoided only by enforcement of the promise." Rest., Contracts $\$ 90$ (1932). 
sideration. Those statutes adopted by a number of states which provide that all written instruments shall import consideration deserve little attention because such laws have been construed to raise only a rebuttable presumption of consideration. ${ }^{\mathrm{I7}} \mathrm{A}$ notable step in the direction of eliminating the necessity of consideration from all written agreements was taken in 1925 by the National Conference of Commissioners on Uniform State Laws when they drafted the Uniform Written Obligations Act. ${ }^{18}$ Professor Williston says it was intended as a modern substitute for the common law seal in order to make gratuitous promises enforceable and it does have that effect. ${ }^{x 9}$ It is wisely limited to written promises, and the requirement that the promisor must express in writing his understanding that his promise will be legally binding upon him prevents casual or hasty promises from becoming more serious than was intended. The difficulty is not with the act but with the apathetic reception accorded it by the state legislatures; only two states have adopted it, the last in $1929 .{ }^{20}$

The Uniform Written Obligations Act applies not only to promises made to amend existing contractual relations but also to promises which create such relations for the first time. However, the crying need, as pointed out above, is for abandonment of the requirement of consideration at the time when the parties to an existing contractual engagement desire to amend it. Many of the cases in which the courts have resorted to questionable reasoning to circumvent the requirement of consideration have arisen in the field of amendments to existing contracts. ${ }^{2 x}$ To meet this problem the state of New York recently adopted an act providing that a revision or amendment of an existing contractual obligation shall not be

\footnotetext{
${ }^{17}$ Smith v. Ohio Millers' Mutual Fire Ins. Co., 330 Mo. 236, 49 S.W. (2d) 42 (1932); Combs v. Combs, I30 Ky. 827, II 4 S.W. 334 (Ig08); Contracts without Consideration; the Seal and the Uniform Written Obligations Act, 3 Univ. Chi. L. Rev. 312, 3I4-15 (1936); The Present Status of the Sealed Obligation, 34 Ill. L. Rev. 457, 464 (r939).

I8 "A written release or promise hereafter made and signed by the person releasing or promising shall not be invalid and unenforceable for lack of consideration, if the writing also contains an additional express statement, in any form of language, that the signer intends to be legally bound." Uniform Written Obligations Act $\$$ I, 9 U.L.A. 352 (Supp. I940). For criticism of the Uniform Written Obligations Act, see Mason, The Utility of Consideration-A Comparative View, 4I Col. L. Rev. 825, 847 (I94I); Reeve, The Uniform Written Obligations Act, 76 U. of Pa. L. Rev. 580 (I928); Steele, The Uniform Written Obligations Act, 2 I Ill. L. Rev. $x 85$ (I926); Contracts without Consideration; The Seal and the Uniform Written Obligations Act, 3 Univ. Chi. L. Rev. 3I2, 325 (1936).

${ }^{29}$ I Williston, Contracts $\S$ Io9, at 374 n. 5 (rev. ed. x936).

${ }^{20} \mathrm{~Pa}$. Stat. Ann. (Purdon, Supp. I94x) tit. 33, § 6; Utah L. (x929) c. 62, repealed by Utah Rev. Stat. Ann. (I933) \& 88-I-2.

2x Note I 5 supra.
} 
invalid for lack of consideration so long as it is in writing and signed by the party sought to be bound by it..22 Such a change in the law is precisely what is required to solve the problem.

In the absence of such a statute as has been enacted in New York, the inability of the parties to make a binding unilateral amendment to an existing contractual relation constitutes a serious defect in our legal technique. Business men believe that amendatory agreements solemnly entered into should be performed by the parties to them, and whenever such agreements are broken, business men have the right to expect the law to supply a remedy. Statements that conduct may be morally wrong but legally right and that the ethical standards of business are frequently more commendable than the edicts of the courts are as hackneyed as they are a condemnation of our legal system. The rules used by the courts in prescribing the rights and liabilities of persons under alleged contracts should be kept abreast of the standards and customs of upright business men. The law merchant must continuously be absorbed into the common law. ${ }^{23}$ Inasmuch as the courts and legislatures have turned a deaf ear to the pleas of business men, a satisfactory technique to achieve the desired end must be developed within the formulae recognized by the courts. With this in mind, it is submitted that the rise of the problem in connection with gratuitous amendments of contractual relations may be anticipated and

22 N.Y.L. (1936) c. $28 \mathrm{r}, \S 2$ : "An agreement hereafter made to change or modify, or to discharge in whole or in part, any contract, obligation, or lease, or any mortgage or other security interest in personal or real property, shall not be invalid because of the absence of consideration, provided that the agreement changing, modifying or discharging such contract, obligation, lease, mortgage or security interest, shall be in writing and signed by the party against whom it is sought to enforce the change, modification or discharge." See Kane Realty Co. v. Nat'l Children's Stores, Inc., I69 Misc. 699, 8 N.Y.S. (2d) 505 (Munic. Ct. I938); Bond, Mortgage \& Securities Co.v. Surplus Wholesale Corp., I62 Misc. 586, 588, 295 N.Y. Supp. 67, 69-70 (Munic. Ct. 1937), discussing the statute. This provision súperseded N.Y.I. (I934) c. I42, $\$ 2$, providing that a written agreement to extend to a fixed date the payment of any obligation is valid without consideration. Cf. N.Y.L. (I936) c. 222 (abrogating consideration requirement for releases). The New York legislature at its last session, while abrogating the effectiveness of the seal as a substitute for consideration (note 12 supra), adopted three acts abolishing the requirement of consideration, where the agreement is in writing and signed by the obligor. N.Y.L. (I94I) c. 328, \$2, subd. 4 (irrevocable offers); N.Y.L. (I94I) c. 330, 82 , subd. 3 (assignments); N.Y.L. (I94I) c. 33I, $\$ 2$, subd. 2 (contracts where the consideration stated is past or executed). For a discussion of the recent New York legislation see Hays, Formal Contracts and Consideration: A Legislative Program, 4I Col. L. Rev. 849 (r94I).

${ }^{23}$ That the view of business men should have an important effect on the law of consideration is suggested by Judge Cardozo's statement, "Courts are not to shut their eyes to the realities of business life." Barkin Construction Co. v. Goodman, 221 N.Y. x56, I6I, II6 N.E. 770, 77I-72 (IgI7). Consult Ames, op. cit. supra note ${ }_{5}$, at 5I8, 53I; Wright, op. cit. supra note I, at 1225, 1232-33, 1247-50; Sharp, Pacta Sunt Servanda, 4I Col. L. Rev. 783, 788 (I94I). 
the problem solved by inserting in every contract, lease, mortgage, and other written engagement having legal consideration a provision substantially similar to that of the New York statute. The following language is suggested:

Any and all agreements hereafter made by the parties hereto to amend, change, extend, revise or discharge this contract [lease, mortgage or other instrument, as the case may be], in whole or in part and on one or more occasions, shall not be invalid or unenforceable because of the lack of consideration, provided that such agreement or agreements to amend, change, extend, revise or discharge this contract [lease, mortgage or other instrument, as the case may be] shall be in writing and executed by the parties hereto.

This provision should operate to bind each party to perform his future gratuitous promises which constitute amendments of the original contract, despite the lack of consideration for such future promises, by reason of his promise in the original contract, for which consideration was furnished by the other party, to be so bound. That satisfies the legal objection. By requiring the future promises to be in writing and signed by all parties to the original agreement before they become binding, persons should not find themselves bound by casual or ill-considered concessions.

From a theoretical point of view it would seem that in making the original agreement, cemented by consideration, the parties could validly agree that all future promises made by either shall be binding upon the promisor despite the lack of consideration, whether such future promises relate to amendments or revisions of the original agreement or to entirely different transactions. Suppose such a broad provision were inserted in a lease and, after the lease expired, the tenant requested his former landlord to loan him a sum of money and the landlord acquiesced in writing. If the landlord should change his mind on the following day, before his former tenant changed his position in reliance on the landlord's promise, it would seem undesirable, but legally proper, to permit the resurrection of the provision from the extinct lease to bind the landlord to his promise. However, so long as the provision is limited to amendments of the original contract, it should operate without undesirable consequences.

Those who have welcomed the requirement of consideration as a bulwark of protection to persons induced by unscrupulous tactics to execute inequitable agreements, such as in the case of a release of liability under a disability policy given by an injured policyholder to the insurance company, and those who have condemned the ancient rule under which seals are permitted to shield such unconscionable agreements from attack, may fear that the clause suggested above will be employed, for example by incor- 
poration in disability policies, as a tool to render unfair agreements binding without any consideration. ${ }^{24}$ The possible abuse of a convenient device should not, however, prove its doom. In addition, it is possible for courts to set aside oppressive agreements, especially between persons in an unequal bargaining position, under or by necessary expansion of the familiar concepts of duress, fraud, and mistake. ${ }^{25}$ It should not be assumed, moreover, that persons in the position of an insurance company usually effect settlements which are unduly favorable to themselves. To the extent that such settlements are equitable, it is socially desirable that they be made but they will not be made if the law does not protect the paying party by holding such settlements to be mutually irrevocable. On the whole, the advantages flowing from the employment of the suggested clause should clearly outweigh whatever abuses may arise.

To create a change in the common law by individual agreement of the parties in each transaction is bound to be slow and unsatisfactory as compared to changes effected by the legislature or the courts. We know, however, that in every agreement, lease, mortgage, or other instrument, certain standardized provisions, designed to regulate the rights of the parties differently from the manner in which such rights would be settled by the law in the absence of agreements by the parties to the contrary, are uniformly inserted with little objection from any of the parties. ${ }^{26}$ The general use of such clauses accomplishes virtually the same effect as legislation or judicial decisions. The provision suggested above could likewise become a standard clause of all agreements and, it is believed, achieve salutary results. ${ }^{27}$

${ }^{24}$ Some Aspects of the Law of Release of Claims in Illinois, 5 Univ. Chi. L. Rev. 455, 462 (1938), urging that the requirement of consideration is a safeguard, however inadequate, against the imposition of unfair agreements when one of the parties is at a serious bargaining disadvantage.

${ }^{25}$ Sharp, op. cit. supra note 23, at 785-88, 796; Some Aspects of the Law of Release of Claims in Illinois, 5 Univ. Chi. L. Rev. 455,463 (r938).

${ }^{26}$ E.g., in leases, the confession clause, provision for lessor's lien on lessee's property, clause enabling lessor to terminate lease in case of lessee's bankruptcy, etc.; in mortgages or trust deeds, provision for acceleration of maturity of the principal payments on any default, exculpatory clauses for the trustee, provision for replacement of lost or destroyed bonds, etc.; and in trust agreements, the so-called "spendthrift" clause, provisions defining the powers and duties of the trustee, clause to avoid the rule against perpetuities, etc.

${ }_{27}$ If that should happen, it would fulfill, at least in part, the prophecy of Sharp, op. cit. supra note 23, at 798: "It may thus be that the further evolution of consideration doctrine will be largely the work of lawyers and judges, in the course of the familiar activities of drafting, advising, negotiation and litigation." 